\title{
APPLICATION OF LIQUID PHOSPHORUS FERTILIZER IMPROVES THE AVAILABILITY OF PHOSPHORUS IN CALCAREOUS SOILS
}

\author{
ERENOĞLU, E. B. ${ }^{*}-$ DÜNDAR, Ş. \\ Department of Soil Science and Plant Nutrition, Faculty of Agriculture, Çukurova University, \\ Adana, Turkey \\ *Corresponding author \\ e-mail: berenoglu@cukurova.edu.tr \\ (Received 17 $7^{\text {th }}$ Dec 2019; accepted $23^{\text {rd }}$ Mar 2020)
}

\begin{abstract}
Increasing the efficiency of phosphorus (P) fertilizers is very important for using natural sources as well as minimizing possible environmental risks. Therefore, the effects of $\mathrm{P}$, applied as monoammonium phosphate (MAP) in different forms (liquid and granule) and soil amendment containing humic-fulvic acids (HA + FA), on the growth and P uptake of model plant bread wheat (Triticum aestivum L. cv. Adana-99) and vertical movement of $\mathrm{P}$ in a calcareous soil were investigated. The application of $\mathrm{P}$ in a liquid form enhanced both $\mathrm{P}$ uptake and shoot growth in comparison to its granule form. However, HA + FA application had no effect on either P uptake or plant growth. Although the $\mathrm{HA}+\mathrm{FA}$ did not affect biomass yield, it had a strengthening effect on vertical movement, even for P applied as a granule. The application of $\mathrm{P}$ in liquid form not only increased $\mathrm{P}$ movement in the soil but also enhanced the $\mathrm{P}$ nutritional status of wheat. In conclusion, the results, in a supportive manner to formerly obtained limited results, showed that the application of $\mathrm{P}$ containing liquid fertilizers, in comparison to granular ones as well as HA + FA addition might increase the efficiency of P fertilizers; and thus enhance yield and minimize the environmental concerns, as well.
\end{abstract}

Keywords: nutrient efficiency, fluid, granule, phosphorus uptake, soil amendment

\section{Introduction}

Increasing human population together with incorrect and unconscious consumption of natural resources necessitates a specific need to increase crop productivity per area. That is why the main objectives of today's agriculture are as follows: i) raising of crop yields to higher levels and ii) sustainability. Increasing the agricultural production to maximum levels will be possible by either expanding production areas or obtaining better yields per area. Since a further increase in existing agricultural areas does not seem feasible/possible, obtaining a higher yield per area appears to be the real target. One of the most critical factors that may ensure higher yields per area in a sustainable manner is sustainable plant production practices. As a well-known phenomenon, nutrient deficiencies are in the forefront among factors limiting the development of sustainable plant production (Fageria and Baligar, 2005) and 30-50\% of the total increase in world food production since the 1950s has come about due to fertilizer additions (Stewart et al., 2005).

Agricultural production depends on phosphorus $(\mathrm{P})$, which is a non-renewable natural resource derived from phosphate rocks (Cordell et al., 2009). However, a conflict exists with regard to how many years the available phosphate resources will last. While van Kauwenbergh (2010) opined that existing phosphate rocks reserves would be exhausted in 300-400 years or more, others emphasize that they would only last for 50-100 years (Cordell et al., 2009). 
As it is well recognized, $\mathrm{P}$ has the highest far-reaching effect after nitrogen $(\mathrm{N})$ in both natural and agricultural ecosystems among fertilizer nutrients (Brady and Weil, 2008). However, approximately 5.7 billion ha of agricultural land on Earth contains $P$ lower than the optimum level (Mouazen and Kuang, 2016).

Soil organic matter, $\mathrm{pH}$, and exchangeable and soluble aluminum ( $\mathrm{Al})$, iron $(\mathrm{Fe})$, and calcium (Ca) affect the availability of P for plant growth (Ulrich and Schnug, 2013). Since the mobility of $\mathrm{P}$ in soils is limited and, what is considered worse, exposed to fixation at high rates, plants cannot use it effectively. Plants can use only 10-25\% of the $\mathrm{P}$ in fertilizers applied to the soil during the application season (Syers et al., 2008). In such a way, plants in the year of application use only a few portions of $\mathrm{P}$ in fertilizers, and the effectiveness of any residual $\mathrm{P}$ fertilizer decreases with time (Lombi et al., 2004a, b).

Alkaline soils represent a very significant part of the agricultural production area of the world (Holloway et al., 2001). According to the Food and Agriculture Organization (FAO), almost 800 million ha of soils worldwide are calcareous and mainly located in arid or semi-arid climates of both hemispheres (FAO, 2001). In general, high pH, clay, lime, and low organic matter are known as factors limiting the availability of $\mathrm{P}$ in soils (Gallet et al., 2003; Franson et al., 2003).

In calcareous soils, the application of fluid forms of $\mathrm{P}$ fertilizers results in higher $\mathrm{P}$ mobility (Lombi et al., 2004 a, b) and availability (Holloway et al., 2001). In the andisols and oxisols, as well, greater $\mathrm{P}$ diffusion is observed with the fluid form in comparison to the granular one (Montalvo et al., 2014), However, in contrast to calcareous soils, the liquid form of $\mathrm{P}$ does not have an enhancing effect on $\mathrm{P}$ availability in andisols and oxisols - lability and solubility (Montalvo et al., 2014).

It is well-known that the addition of soil amendments such as HA + FA may have positive effects on plant growth (Arjumend et al., 2015; Canellas and Olivares, 2014; Quilty and Cattle, 2011) and support the root development (Canellas and Olivares, 2014; Quilty and Cattle, 2011). Also, this application may increase the mobility/availability of fertilizer P (Zhen-Yu et al., 2013) and its recovery (Delgado et al., 2002).

For the above-mentioned reasons, it was evident that studies aimed at increasing the efficiency of $\mathrm{P}$ containing fertilizers may have outstanding contributions to plant production, thereby quelling the environmental concerns. Therefore, using a subsoil known for its low $\mathrm{P}$ availability and low $\mathrm{P}$ fertilizer use efficiency due to high $\mathrm{pH}$, clay content, lime, and few organic matter, two experiments were designed. In the first experiment, to view the effects of different forms of MAP (fluid or granular) and soil amendment (HA + FA) applications on growth and P uptake, a pot experiment was set up using bread wheat (Triticum aestivum) as a model plant. Also, a column experiment was set up to analyze the effects of the above-mentioned variants on vertical $\mathrm{P}$ transport.

\section{Materials and methods}

\section{Experimental soil and basal fertilization}

The soil material used in the present work was clayey $(63.5 \%$ clay, $19.6 \%$ sand, $16.9 \%$ silt), calcareous $\left(17.8 \% \mathrm{CaCO}_{3}\right)$, alkaline $(\mathrm{pH} 7.5)$, and low organic matter containing $(0.12 \% \mathrm{OM})$ subsurface soil. The available $\mathrm{P}$ and potassium (K) contents of soil were found to be $1.5 \mathrm{~kg} \mathrm{P}_{2} \mathrm{O}_{5} \cdot \mathrm{ha}^{-1}$ and $462 \mathrm{~kg} \mathrm{~K}_{2} \mathrm{O} \cdot \mathrm{ha}^{-1}$, respectively. 
The experimental soil was fertilized with the following rates of basal nutrients (in $\mathrm{mg} \cdot \mathrm{kg}^{-1}$ soil): $200 \mathrm{~N}$ (as $\mathrm{NH}_{4} \mathrm{NO}_{3}+[\mathrm{MAP}]$ ), $100 \mathrm{~K}$ (as $\mathrm{K}_{2} \mathrm{SO}_{4}$ ), $5.0 \mathrm{Fe}$ (as $\mathrm{Fe}(\mathrm{III}) \mathrm{EDDHA}, 2.5 \mathrm{Zn}$ (as $\mathrm{ZnSO}_{4} \cdot 7 \mathrm{H}_{2} \mathrm{O}$ ), $2.5 \mathrm{Mn}$ (as $\mathrm{MnSO}_{4}$ ), and $1.0 \mathrm{Cu}$ (as $\mathrm{CuSO}_{4} \cdot 7 \mathrm{H}_{2} \mathrm{O}$ ). As mentioned earlier, the soil had very low $\mathrm{P}$ availability, so a basal $\mathrm{P}$ fertilization was also included in the amount of $5.0 \mathrm{mg} \cdot \mathrm{kg}^{-1}$ soil as TSP. Since varied amounts of $\mathrm{NH}_{4}-\mathrm{N}$ came from different rates of MAP, after subscription of those $\mathrm{NH}_{4}-\mathrm{N}$ amounts from the total $\mathrm{N}\left(200 \mathrm{mg} \cdot \mathrm{kg}^{-1}\right.$ soil $)$, the rest of it was added using $\mathrm{NH}_{4} \mathrm{NO}_{3}$.

\section{Fertilizer forms, $\mathrm{HA}+\mathrm{FA}$, and P uptake - Experiment I}

In this part, a pot experiment was conducted in a growth chamber under controlled climatic conditions [light:dark periods, $16: 8 \mathrm{~h}$; temperature (light:dark), 22:18 ${ }^{\circ} \mathrm{C}$; relative humidity (light:dark), 60:70\%; photosynthetic flux density, $250 \mu \mathrm{mol} \mathrm{m}^{-2} \mathrm{~s}^{-1}$ ] to view the effects of fertilizer forms and their application rates, presence of $\mathrm{HA}+\mathrm{FA}$ mixture as soil amendments on plant growth, and $\mathrm{P}$ uptake using pots contained $1 \mathrm{~kg}$ of soil in each. For this, a bread wheat cultivar (Triticum aestivum L cv. Adana-99) was used as a model plant. While MAP-P was added at three rates $(0,25,50$, and $100 \mathrm{mg}$ $\mathrm{P} \cdot \mathrm{kg}^{-1}$ soil $)$ as either granule or fluid, $\mathrm{HA}+\mathrm{FA}$ mixture was applied at two rates $(0$ and $125 \mathrm{mg}[\mathrm{HA}+\mathrm{FA}] \cdot \mathrm{kg}^{-1}$ soil) using a commercial product (TKI-Hümas, Coal Enterprises Association of Turkey). The HA + FA mixture, together with other basal nutrients (given above) was mixed with soil. Thereafter, all of the granular and fluid MAP applications were performed $2.5 \mathrm{~cm}$ below the soil surface shortly before sowing. While granule numbers were kept equal for each rate of $\mathrm{P}$ (6 granules per pot) to eliminate the effect of spatial variations, liquid applications were performed in $50 \mathrm{~mL}$ of distilled water. After sowing five seeds per pot, seedlings were thinned to 3 plants $\cdot$ pot $^{-1}$. Every two days, pots were regularly weighed and watered at $50 \%$ of the field capacity for the first week and $75 \%$ for the following weeks. At the end of the 30-day experimental period, the shoots were harvested, dried at $65^{\circ} \mathrm{C}$, weighed, and dry ashed; then, $\mathrm{P}$ concentrations were determined. After the above-ground parts were cut off, the roots in pots were washed carefully with deionized water, and dried at $65{ }^{\circ} \mathrm{C}$ to measure their dry weights. Thereafter, their P contents were determined as well.

\section{Fertilizer forms, $\mathrm{HA}+\mathrm{FA}$, and vertical P transport - Experiment II}

A disrupted soil column experiment was designed to investigate the effects of fertilizer forms and HA + FA on the vertical transport of $\mathrm{P}$ in soil. Here, columns prepared with an inner diameter of $6.9 \mathrm{~cm}$ and a height of $23 \mathrm{~cm}$ were used (Fig. 1A). In the middle of the $0-5 \mathrm{~cm}, 5-10 \mathrm{~cm}, 10-15 \mathrm{~cm}$, and $15-20 \mathrm{~cm}$ sections below the first $3 \mathrm{~cm}$ from the top, there were $4 \mathrm{~mm}$ holes in which soil solution sampling sticks of 2.5 $\mathrm{mm}$ diameter existed. The columns were filled with soil subjected to incubation with 5 or $100 \mathrm{mg} \mathrm{P} \cdot \mathrm{kg}^{-1}$ soil, with or without application of $\mathrm{HA}+\mathrm{FA}$ at $125 \mathrm{mg} \mathrm{HA}+\mathrm{FA} \cdot \mathrm{kg}^{-1}$ soil level for two weeks, at a bulk density of $1.1 \mathrm{~g} \mathrm{~cm}^{3}$. In the experiment, the application forms were a granular and fluid MAP, and the application dose was $100 \mathrm{mg}$ $\mathrm{P} \cdot \mathrm{kg}^{-1}$ soil. Both types of MAP were employed $2.5 \mathrm{~cm}$ below the soil surface, and deionized water was added to the columns until they reached field capacity. Twentyfour hours after application, the samples of soil solution were taken using soil solution samplers (Rhizone Sampling), which were made of a porous plastic material (Fig. 1B) and sucking them with the help of vacuum tubes. Since the pore diameters of the samplers are $0.15 \mu \mathrm{m}$, the P measured in the solutions obtained is deemed to be colloid- 
free soil solution P (McDowell and Sharply, 2001; Shand et al., 2000). Since the sophistication of experimental design (especially solution sampling step) would not let us have multiple replicas in Experiment II, statistical analysis was not applicable.

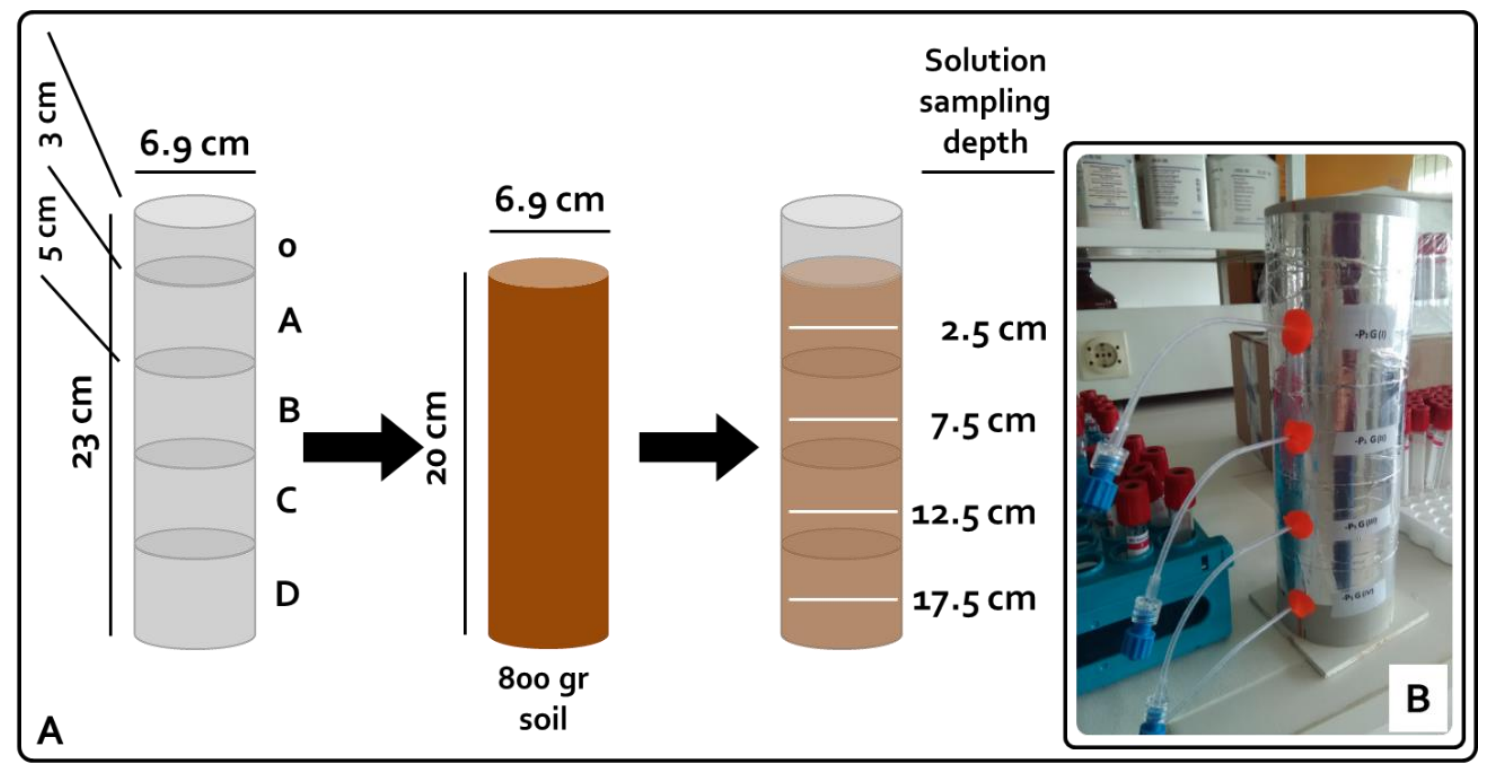

Figure 1. Experimental design of fertilizer forms, $H A+F A$, and vertical $P$ transport experiment. (A) Design of a column and solution sampling points in it and (B) a column ready for sampling

\section{Statistics}

All the values obtained in Experiment I were subjected to analysis of variance using the statistical package software 'SPSS STATISTICS 20'. Since there was no statistical effect of HA + FA recorded for each parameter measured, traits with or without HA + FA application were evaluated separately. The averages of measured parameters with different traits were compared using the Duncan test at the probability level of $\mathrm{P} \leq 0.05$, and the differentiating averages were shown with different characters.

\section{Results}

\section{Fertilizer forms, $\mathrm{HA}+\mathrm{FA}$, and P uptake - experiment I}

\section{Plant growth}

Even though soils fertilized with a basal P level of $5 \mathrm{mg} \mathrm{P} \cdot \mathrm{kg}^{-1}$ soil, due to shallow Olsen P level of soil, were used in the experiment, the control plants showed very severe P deficiency symptoms. On day 24 , grayish-brown necrosis, which was different from typical $\mathrm{P}$ deficiency symptoms such as growth regression in shoot growth and purpling on old leaves, was visible. As the symptoms on control plants became severe, the experiment was terminated on day 30.

The plant observations at harvest showed that $\mathrm{P}$ application, together with increments in $\mathrm{P}$ rates, had a positive effect on plant growth. In Table 1, there are some growth parameters such as shoot and roots dry weights and root-to-shoot ratios. As given in this 
table and Figure 2, the P applied in the fluid form of the MAP showed a statistically important higher effect on the shoot growth of plants compared to the ones supplied with the granular MAP. Compared to plants provided with the fluid MAP, root/shoot ratios, an indicator of $\mathrm{P}$ nutrition of plants, of plants fertilized with granule MAP in both the presence and absence of HA + FA were higher, and this was statistically important (Table 1). Although increasing $\mathrm{P}$ application rates had a positive effect on both shoot and root dry weights of bread wheat, HA + FA mixture used as soil amendments did not affect plant growth (Table 1). Also, Figure 2 taken on the day of harvest shows that independent of HA + FA application, tillering density and stalk thickness was higher in plants supplied with a fluid MAP than granule MAP.

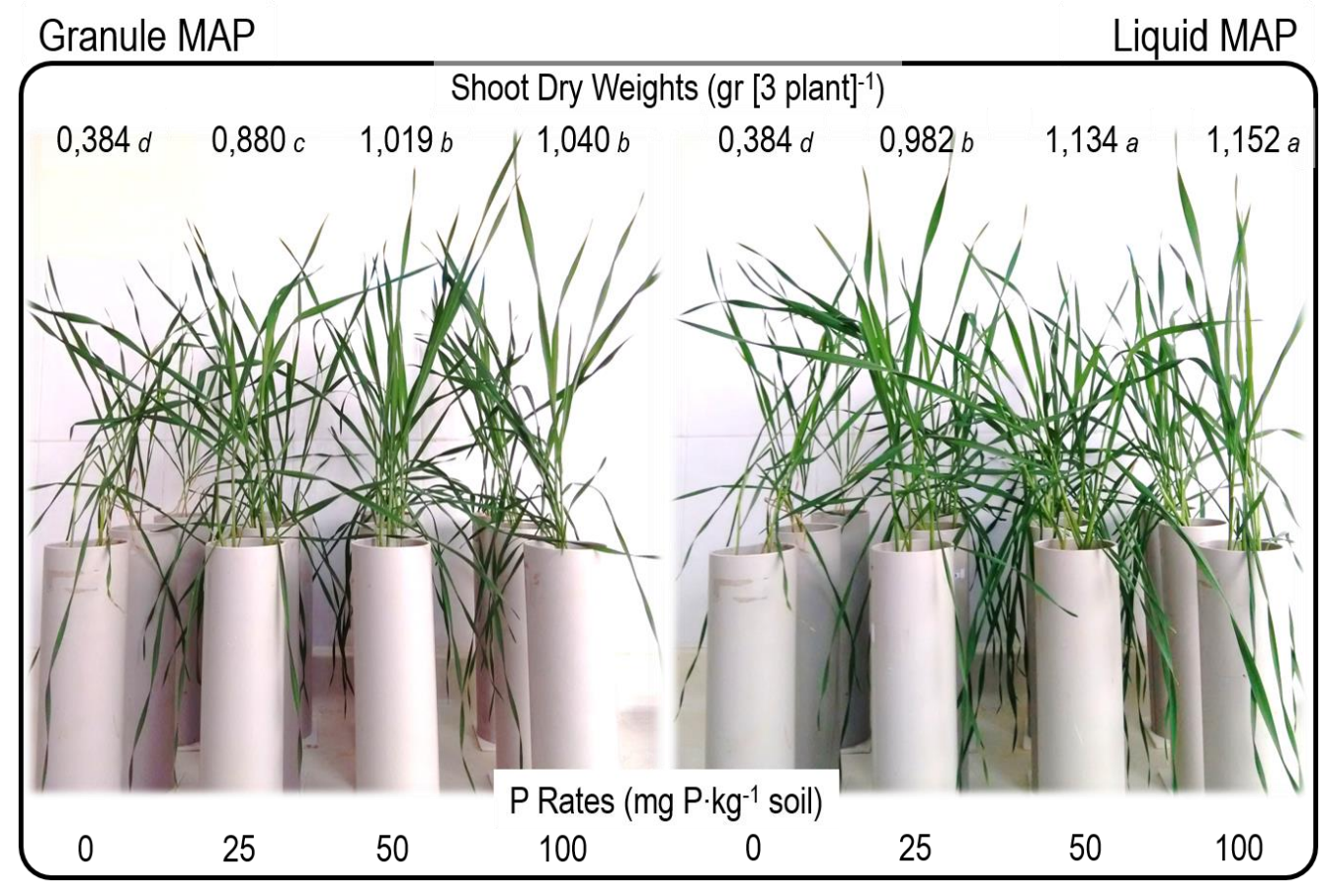

Figure 2. Shoot dry weights and growth of model plant bread wheat grown with fluid or granule forms of the MAP and different $P$ rates $(-[H A+F A])$. Dry weight values are means of three independent replicates. For each trait, numbers with different letters are significantly different from each other at $p<0.05$, according to ANOVA and Duncan's test

\section{Phosphorus uptake}

As clearly seen in Table 2, independent of the application form of MAP-P and $\mathrm{HA}+\mathrm{FA}$ addition, increasing rates of $\mathrm{P}$ moved the $\mathrm{P}$ contents per shoot or root dry matter up in comparison to the control plant. However, this increment was more evident for the plants grown with fluid MAP, and the effect was statistically significant as well. Even the P concentration in the shoot of plant supplied with the fluid MAP at the lowest $\mathrm{P}$ rate was higher than granule applications at all P levels without HA + FA (Table 2). Parallel to this, when plants were supplied with HA + FA, the P concentration in the shoot of plants supplied with the fluid MAP at the lowest $\mathrm{P}$ rate was similar to plants provided with granule MAP at the highest $\mathrm{P}$ rate and higher than the other two lower $\mathrm{P}$ rates (Table 2). 
Table 1. Shoot and root dry weights and roots to shoot ratio of model plant bread wheat grown with granule or fluid forms of the MAP and different $P$ rates and with or without $H A+F A$ application. The values are the means of three independent replicates. For each trait, numbers with different letters are significantly different from each other at $p<0.05$, according to ANOVA and Duncan's test

\begin{tabular}{|c|c|c|c|c|}
\hline \multirow[t]{2}{*}{ Fertilizer form } & \multirow{2}{*}{$\begin{array}{c}\text { P rates } \\
\left(\mathrm{mg} \mathrm{P}^{-1} \mathbf{~ g}^{-1} \text { soil }\right)\end{array}$} & \multicolumn{2}{|c|}{$\begin{array}{c}\text { Dry weights } \\
\left(\mathrm{g}[3 \text { plants] }]^{-1}\right)\end{array}$} & \multirow[t]{2}{*}{ Roots/shoot } \\
\hline & & Shoot & Roots & \\
\hline & & \multicolumn{3}{|c|}{$-[\mathrm{HA}+\mathrm{FA}]$} \\
\hline- & 0 & $0.38 \mathrm{~d}$ & $0.16 \mathrm{c}$ & $0.41 \mathrm{ab}$ \\
\hline \multirow{3}{*}{ 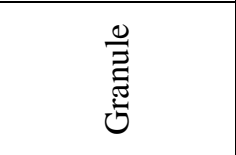 } & 25 & $0.88 \mathrm{c}$ & $0.39 \mathrm{ab}$ & $0.45 \mathrm{a}$ \\
\hline & 50 & $1.02 \mathrm{~b}$ & $0.43 \mathrm{a}$ & $0.42 \mathrm{a}$ \\
\hline & 100 & $1.04 \mathrm{~b}$ & $0.43 \mathrm{a}$ & $0.41 \mathrm{ab}$ \\
\hline \multirow{4}{*}{ 䒜 } & 25 & $0.98 \mathrm{~b}$ & $0.38 \mathrm{ab}$ & $0.39 \mathrm{ab}$ \\
\hline & 50 & $1.13 \mathrm{a}$ & $0.35 \mathrm{~b}$ & $0.31 \mathrm{c}$ \\
\hline & 100 & $1.15 \mathrm{a}$ & $0.42 \mathrm{a}$ & $0.36 \mathrm{bc}$ \\
\hline & & \multicolumn{3}{|c|}{$+[\mathrm{HA}+\mathrm{FA}]$} \\
\hline- & 0 & $0.37 \mathrm{e}$ & $0.19 \mathrm{~d}$ & $0.49 \mathrm{a}$ \\
\hline \multirow{3}{*}{ 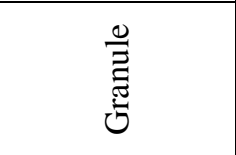 } & 25 & $0.83 \mathrm{~d}$ & $0.36 \mathrm{abc}$ & $0.43 \mathrm{abc}$ \\
\hline & 50 & $0.92 \mathrm{~cd}$ & $0.42 \mathrm{ab}$ & $0.45 \mathrm{a}$ \\
\hline & 100 & $1.00 \mathrm{bc}$ & $0.44 \mathrm{a}$ & $0.44 \mathrm{ab}$ \\
\hline \multirow{3}{*}{ 䒜 } & 25 & $0.92 \mathrm{~cd}$ & $0.33 \mathrm{c}$ & 0.36 bcd \\
\hline & 50 & $1.07 \mathrm{ab}$ & $0.34 \mathrm{bc}$ & $0.32 \mathrm{~d}$ \\
\hline & 100 & $1.12 \mathrm{a}$ & $0.39 \mathrm{abc}$ & $0.35 \mathrm{~cd}$ \\
\hline
\end{tabular}

Table 2. Phosphorus contents per shoot and roots dry weights (\%) in shoot and roots of model plant bread wheat grown with granule or fluid forms of the MAP and different $P$ rates and with or without HA +FA application. The values are the means of three independent replicates. For each trait, numbers with different letters are significantly different from each other at $p<0.05$, according to ANOVA and Duncan's test

\begin{tabular}{|c|c|c|c|c|c|}
\hline \multirow{3}{*}{$\begin{array}{l}\text { Fertilizer } \\
\text { form }\end{array}$} & \multirow{3}{*}{$\begin{array}{c}\text { P rates } \\
\left(\mathrm{mg} \mathrm{P}^{\prime} \cdot \mathrm{kg}^{-1} \text { soil }\right)\end{array}$} & \multicolumn{4}{|c|}{$\begin{array}{c}\text { P concentration } \\
(\%)\end{array}$} \\
\hline & & \multicolumn{2}{|c|}{ - $[\mathrm{HA}+\mathrm{FA}]$} & \multicolumn{2}{|c|}{$+[\mathrm{HA}+\mathrm{FA}]$} \\
\hline & & Shoot & Roots & Shoot & Roots \\
\hline- & 0 & $0.17 d$ & $0.11 e$ & $0.16 d$ & $0.13 d$ \\
\hline \multirow{3}{*}{$\begin{array}{l}\stackrel{\circlearrowright}{\Xi} \\
\text { 륨 }\end{array}$} & 25 & $0.22 c$ & $0.14 d e$ & $0.21 c$ & $0.16 c d$ \\
\hline & 50 & $0.26 b$ & $0.16 c d$ & $0.24 c$ & $0.15 c d$ \\
\hline & 100 & $0.28 b$ & $0.21 a b$ & $0.28 b$ & $0.20 b$ \\
\hline \multirow{3}{*}{ : } & 25 & $0.30 b$ & $0.18 b c$ & $0.27 b$ & $0.18 b c$ \\
\hline & 50 & $0.37 a$ & $0.22 a$ & $0.36 a$ & $0.25 a$ \\
\hline & 100 & $0.39 a$ & $0.21 a b$ & $0.37 a$ & $0.26 a$ \\
\hline
\end{tabular}

As a result of better growth and higher $\mathrm{P}$ uptake, independent of the application forms of MAP and HA + FA application, increasing rates of $\mathrm{P}$ enhanced the $\mathrm{P}$ content 
per shoot, roots, and whole plant in comparison to control plants (Table 3). Moreover, with or without soil amendment application, the P content per shoot, roots, and whole plant in plants grown with fluid or granule form of MAP considered together, it was seen that plants supplied with fluid ones had higher P contents and this difference was statistically significant (Table 3). The $\mathrm{P}$ content per plant with or without $\mathrm{HA}+\mathrm{FA}$ application showed that there was no difference among the plants.

Table 3. Phosphorus contents per shoot, roots, shoot, and the whole plant in shoot and roots of model plant bread wheat grown with granule or fluid forms of the MAP and different $P$ rates and with or without $H A+F A$ application. The values are the means of three independent replicates. For each trait, numbers with different letters are significantly different from each other at $p<0.05$, according to ANOVA and Duncan's $t$-test

\begin{tabular}{|c|c|c|c|c|}
\hline \multirow{3}{*}{$\begin{array}{l}\text { Fertilizer } \\
\text { form }\end{array}$} & \multirow{3}{*}{$\begin{array}{c}\text { P rates } \\
\left(\mathrm{mg} \mathrm{P} \mathrm{kg}^{-1} \text { soil }\right.\end{array}$} & \multicolumn{3}{|c|}{$\begin{array}{c}\text { P uptake } \\
\left(\mathrm{mg} \mathrm{P} \cdot[3 \text { plants }]^{-1}\right)\end{array}$} \\
\hline & & Shoot & Roots & Shoot + roots \\
\hline & & \multicolumn{3}{|c|}{$-[\mathrm{HA}+\mathrm{FA}]$} \\
\hline- & 0 & $0.66 d$ & $0.17 e$ & $0.84 d$ \\
\hline \multirow{3}{*}{ } & 25 & $1.97 c$ & $0.53 d$ & $2.50 c$ \\
\hline & 50 & $2.67 b$ & $0.70 b c$ & $3.37 b$ \\
\hline & 100 & $2.88 b$ & $0.90 a$ & $3.78 b$ \\
\hline \multirow{4}{*}{$\frac{\overline{3}}{3}$} & 25 & $2.90 b$ & $0.68 c d$ & $3.58 b$ \\
\hline & 50 & $4.17 a$ & $0.77 a b c$ & $4.94 a$ \\
\hline & 100 & $4.50 a$ & $0.85 a b$ & $5.35 a$ \\
\hline & & \multicolumn{3}{|c|}{$+[\mathrm{HA}+\mathrm{FA}]$} \\
\hline- & 0 & $0.60 f$ & $0.23 d$ & $0.83 f$ \\
\hline \multirow{3}{*}{ } & 25 & $1.75 e$ & $0.57 c$ & $2.33 e$ \\
\hline & 50 & $2.18 d$ & $0.61 b$ & $2.81 d$ \\
\hline & 100 & $2.84 c$ & $0.90 a$ & $3.74 c$ \\
\hline \multirow{3}{*}{$\frac{.}{3}$} & 25 & $2.53 c$ & $0.59 b$ & $3.12 d$ \\
\hline & 50 & $3.81 b$ & $0.84 a$ & $4.65 b$ \\
\hline & 100 & $4.18 a$ & $1.03 a$ & $5.21 a$ \\
\hline
\end{tabular}

\section{Fertilizer forms, $\mathrm{HA}+\mathrm{FA}$, and vertical P transport - Experiment II}

The results of the disrupted soil column experiment, which was conducted to investigate the effects of fertilizer forms and rates and HA + FA on the vertical transport of $\mathrm{P}$ in the soil, are displayed in Table 4. As mentioned above, the columns prepared with an inner diameter of $6.9 \mathrm{~cm}$ and a height of $23 \mathrm{~cm}$ were used (Fig. 1A), and $\mathrm{P}$ was applied either as fluid or granule to the horizontal mid-point of the top cylinder. After a 24-h incubation period, the soil solution samples were taken from the middle of each cylinder using a soil solution sampler to analyze them for P (Fig. 1B).

Table 4 shows the $\mathrm{P}$ concentrations in soil solution samples. As it is clearly reflected, the vertical movement of MAP-P, which was applied as granule with or without HA + FA application, was much lower than when it was applied as fluid. In the columns supplied with the granule MAP-P and no soil amendment, and in the soil solution samples taken from $7.5 \mathrm{~cm}$ and deeper, no $\mathrm{P}$ was measurable, showing bordered movement of $\mathrm{P}$ (Table 4). However, even in the soil solution samples taken from the 
mid-point (15 cm away from application point) of the bottom-standing cylinder of columns, the P could be measured $24 \mathrm{~h}$ after application. Phosphorus could be detected even in the soil solution samples taken $5 \mathrm{~cm}$ below application points of columns precultured with HA + FA and to which the granule MAP-P was applied, as opposed to columns precultured without HA + FA.

Table 4. The P concentrations in the soil solution samples taken from the application points and vertically 5,10 , and $15 \mathrm{~cm}$ away from them in the columns pre-cultured 5 or $100 \mathrm{mg}$ $P \cdot \mathrm{kg}^{-1}$ soil and with or without HA + FA for two weeks

\begin{tabular}{c|c|c|c|c|c|c}
\hline $\begin{array}{c}\text { Pre-culture } \\
\left(\mathbf{m g ~ k g}^{-1} \text { soil) }\right.\end{array}$ & & $\begin{array}{c}\text { Fertilizer } \\
\text { form }\end{array}$ & \multicolumn{4}{|c}{ The position of sampling stick $(\mathbf{c m}$ from the top of soil surface } \\
\hline HA + FA & P & & 2.5 & 7.5 & 12.5 & 17.5 \\
\hline \multirow{4}{*}{-} & 5 & \multirow{2}{*}{ Granule } & 6.34 & 0.00 & 0.00 & 0.00 \\
& 100 & & 19.24 & 0.00 & 0.00 & 0.00 \\
\cline { 2 - 7 } & 5 & \multirow{2}{*}{ Fluid } & 2.91 & 1.31 & 1.00 & 0.26 \\
& 100 & & 3.87 & 4.18 & 0.50 & 0.00 \\
\hline & 5 & \multirow{2}{*}{ Granule } & 5.87 & 1.37 & 0.00 & 0.00 \\
+ & 100 & & 5.09 & 1.15 & 0.00 & 0.00 \\
\cline { 2 - 7 }+ & 5 & \multirow{2}{*}{ Fluid } & 1.29 & 1.10 & 0.30 & 0.10 \\
& 100 & & 1.97 & 7.26 & 1.60 & 1.20 \\
\hline
\end{tabular}

Moreover, the mobility of $\mathrm{P}$ in the columns supplied with the fluid MAP and precultured with $\mathrm{HA}+\mathrm{FA}$ and $100 \mathrm{mg} \mathrm{P} \cdot \mathrm{kg}^{-1}$ soil was even better than columns without $\mathrm{HA}+\mathrm{FA}$; even the solution samples taken from $15 \mathrm{~cm}$ away from application point contained higher $\mathrm{P}$ concentrations. However, there were no apparent differences in the $\mathrm{P}$ movement of soils pre-cultured with different amounts of $\mathrm{P}$ within a given form of MAP fertilizer.

\section{Discussion}

According to Fageria and Baligar (2005), one of the essential details that cause problems in sustainable crop production is the inadequacy of nutrient element(s). The nutrient capital of soils is not unlimited and should be renewed depending on the amounts of nutrients removed from the land. In addition to this renewal, the primary aim involves minimizing the risk of environmental contamination and maximizing the contribution of plant nutrients to vegetative production by ensuring the most effective use of the nutrients by plants.

Although the most critical roles of $\mathrm{P}$ in vegetative life are energy transfer and storage, it is also found in the structure of many components, which are essential for growth and development, such as nucleic acids, nucleotides, coenzymes, phospholipids, phosphoproteins, and sugar phosphates (Vance et al., 2003). Incongruity involves an increase in the shoot growth of model plant wheat with the $\mathrm{P}$ application as well as an increase in $\mathrm{P}$ rates (Table 2) fitted well in those roles of $\mathrm{P}$ in plant nutrition. However, gray-brown necrosis and very severe growth regression differed from the typical $\mathrm{P}$ deficiency symptoms of regressive growth and purpling in old leaves (Snowball and Robson, 1983) of control plants cultivated on the experimental soil with very low 
available $\mathrm{P}$ being observed. The reason for this might be the problems encountered with the use of photosynthesis products and that occur in severe $\mathrm{P}$ deficiency (Carstensen et al., 2018). Moreover, independent of HA + FA application, the higher roots-to-shoot ratios of plants supplied with granule MAP in comparison to the plants provided with the fluid form of MAP (Table 3) may be an indicator of severe P deficiency (Andrews et al., 1999; Zhang et al., 2012).

Although increasing rates of $\mathrm{P}$ increased both shoot and roots growths, the soil amendment application had no positive effect on plant growth (Table 3). This result was in contrast to the results of those studies in which the HA + FA mixture had positive effects on plant growth (Arjumend et al., 2015; Canellas and Olivares, 2014; Quilty and Cattle, 2011). The possible reason for this might be the termination of the experiment after 30 days, as the control plant showed fast and severe P deficiency stress due to very low organic matter content $(0.12 \%)$ or very low Olsen P in the soil. It is a well-known phenomenon that the root growth is very active on P uptake (Wang et al., 2016), and HA + FA supports the development of root growth (Canellas and Olivares, 2014; Chunhua et al., 1998; Quilty and Cattle, 2011). Due to the limited volume of soil in a narrow design pot, the superior effect of HA + FA application on root growth in comparison to plants grown without HA + FA might have been prevented, since the roots of plants grown without HA + FA application could easily reach to the nutrients in the pots.

Consistent with a study carried out in the calcareous soils of Australia by Holloway and colleagues (2001), the plant observations as well as the shoot dry weights (Table 1) obtained from the harvested plants on the 30th day after planting indicated that fluid $\mathrm{P}$ improved the plant development relative to granule. As mentioned before, roots/shoot ratio is an indication of $\mathrm{P}$ nutrition in plants, as it increases when they suffer from $\mathrm{P}$ deficiency (Andrews et al., 1999; Zhang et al., 2012). Accordingly, the model plant wheat supplied with no $\mathrm{P}$ or granular MAP-P, irrespective of soil amendments application, had higher root-to-shoot ratio values than plants supplied with fluid MAP-P with the same rates of granule ones (Table 1). It is well known that $\mathrm{P}$ moves in soil with diffusion (Marschner, 2012), and its application in fluid form in calcareous soils showed higher mobility and distribution than its granular forms (Lombi et al., 2004a, b). Therefore, the higher root/shoot ratios of plants, grown with granule MAP-P as in control plants and in comparison to plants fertilized with fluid MAP-P (Table 1), might be the higher $\mathrm{P}$ deficiency stress as a result of limited $\mathrm{P}$ mobility in case of granular MAP-P application. Lower P concentrations in the shoots of plants supplied with granular MAP-P compared to the plants grown with the same rates of the fluid MAP (Table 2) also supports the argument. This result is consistent with the knowledge that $\mathrm{P}$ applied to the band as a fluid responds better than in the granular form (Holloway et al., 2001). However, although they had found a supporting effect of fluid $P$ application on grain yield of wheat in the field conditions, they did not observe any increase in $\mathrm{P}$ concentrations in the leaf tissue (Holloway et al., 2001).

According to the growth parameters (Table 1) and $\mathrm{P}$ nutritional status (Tables 2 and 3 ) of model plant wheat, the application of $\mathrm{P}$ as fluid instead of granular improved its mobility in the soil (Table 4). In the common opinion, while the $\mathrm{P}$ precipitation occurs at high concentrations of soil solution $\mathrm{P}$, the $\mathrm{P}$ adsorption takes place at low levels (Castro and Torrent, 1998; Saavedra and Delgado, 2005). Therefore, it might be assumed that the precipitation of Ca-phosphates arises in the soil surrounding fertilizer granule where the P concentration is higher than the bulk soil (Holloway et al., 2001; 
Lombi et al., 2004a, b). So, the reason for higher mobility (or longer vertical movement) of $\mathrm{P}$ applied as the fluid MAP (Table 4) might be less Ca-phosphate precipitation in comparison to the granular MAP application. However, in contrast to calcareous soils, although the liquid form of $\mathrm{P}$ may increase the mobility of $\mathrm{P}$ in andisols and oxisols, it does not have an enhancing effect on $\mathrm{P}$ availability - lability and solubility (Montalvo et al., 2014). It is known that organic compounds may decrease the $P$ fixation capacity of soils (Brady and Weil, 2008), and humates can bind P (von Wandruszka, 2006). Parallel to this, the application of HA + FA caused an increment even in the mobility of $\mathrm{P}$ applied in the granular form. This result fits well with the results of a study showing that HA application supports the movement of MCP-P to long distances, thereby increasing its mobility (Zhen-Yu et al., 2013).

Moreover, in a survey conducted by Delgado et al. (2002), the soil amendment with HA + FA increased the recovery of fertilizer P. However, in that study, they had tested extremely high amounts of HA + FA (from 1000 to $5000 \mathrm{mg}[\mathrm{HA}+\mathrm{FA}] \cdot \mathrm{kg}^{-1}$ soil) which were much higher than applied in practice. Also, all the experiments related to the mobility of $\mathrm{P}$ in soils had been conducted during an extended incubation period (Delgado et al., 2002; Lombi et al., 2004a, b; Zhen-Yu et al., 2013), but in the present work, we analyzed the mobility of $\mathrm{P}$ in a period as limited as $24 \mathrm{~h}$.

\section{Conclusions}

Our study, propelled by limited previous research activities, showed that liquid forms of $\mathrm{P}$ containing fertilizers might increase the efficiency of $\mathrm{P}$ fertilizers, expanding both $\mathrm{P}$ mobility and availability in soils with high $\mathrm{CaCO}_{3}$ and clay. As a natural result of it, the $\mathrm{P}$ application in the form of the fluid MAP led to higher uptake of $\mathrm{P}$ than plants supplied with the granular MAP. Therefore, under suitable conditions/regions, the growers may prefer liquid forms of $\mathrm{P}$ containing fertilizers to ensure higher yields and protect the environment from the hazardous effect of excess P. However, to test the actual contribution of this phenomenon, additional experiments are needed under field conditions. Moreover, the addition of HA + FA enhanced the mobility of P in the soil in both forms of MAP, in particular, fluid form of it. Although such an amendatory effect of HA + FA on P mobility existed, its application did not play a decisive role in either the growth or $\mathrm{P}$ uptake of the model plant. The reason for this might be the extreme behaviors of experimental materials such as soil with extremely low $\mathrm{OM}$ and plant available $\mathrm{P}$ or very narrow designed pots. Further detailed experiments are required to clarify this point.

Acknowledgments. The present manuscript was prepared using the results of Şeyhmus Dündar's MSc thesis, which was granted by the Scientific Research Projects Coordination Unit at Çukurova University.

\section{REFERENCES}

[1] Andrews, M., Sprent, J. I., Raven, J. A., Eady, P. E. (1999): Relationships between shoot to root ratio, growth and leaf soluble protein concentration of Pisum sativum, Phaseolus vulgaris and Triticum aestivum under different nutrient deficiencies. - Plant Cell \& Environment 22: 949-958. 
[2] Arjumend, T., Abbasi, M. K., Rafique, E. (2015): Effects of lignite derived humic acid on some selected soil properties, growth and nutrient uptake of wheat (Triticum aestivum L.) grown under greenhouse conditions. - Pakistan Journal of Botany 47: 2231-2238.

[3] Brady, N. C., Weil, R. R. (2008): The Nature and Properties of Soils. - Pearson-Prentice Hall, Upper Saddle River, NJ.

[4] Canellas, L. P., Olivares, F. L. (2014): Physiological responses to humic substances as plant growth promoter. - Chemical and Biological Technologies in Agriculture 1: 3. https://doi.org/10.1186/2196-5641-1-3.

[5] Carstensen, A., Herdean, A., Schmidt, S. B., Sharma, A., Spetea, C., Pribil, M., Husted, S. (2018): The impacts of phosphorus deficiency on the photosynthetic electron transport chain. - Plant Physiology 177: 271-284.

[6] Castro, B., Torrent, J. (1998): Phosphate sorption by calcareous Vertisols and Inceptisols as evaluated from extended P-sorption curves. - European Journal of Soil Science 49: 661-667.

[7] Chunhua, L., Cooper, R. J., Bowman, D. C. (1998): Humic acid application affects photosynthesis, root development, and nutrient content of creeping bentgrass. HortScience 33: 1023-1025.

[8] Cordell, D., Drangert, J. O., White, S. (2009): The story of phosphorus: global food security and food for thought. - Global Environmental Change 19: 292-305.

[9] Delgado, A., Madrid, A., Kassem, S., Andreu, L., del Campillo, M. D. C. (2002): Phosphorus fertilizer recovery from calcareous soils amended with humic and fulvic acids. - Plant and Soil 245: 277-286.

[10] Fageria, N. K., Baligar, V. C. (2005): Enhancing nitrogen use efficiency in crop plants. Advances in Agronomy 88: 97-185.

[11] FAO (2001): World Soil Resources Reports 94. - Lecture Notes on the Major Soils of the World. FAO, Rome.

[12] Franson, A., Aarle, I. M., Olsson, P. A., Tyler, G. (2003): Plantago lanceolata L. and Rumex acetosella L. differ in their utilization of soil phosphorus fractions. - Plant and Soil 248: 285-295.

[13] Gallet, A., Flish, R., Ryser, J., Nosberger, J., Frossard, E., Sinaj, S. (2003): Uptake of residual phosphate and freshly diammonium phosphate by Lolium perenne and Trifolium repens. - Journal of Plant Nutrition and Soil Science166: 557-567.

[14] Holloway, R. E., Bertrand, I., Frischke, A. J., Brace, D. M., McLaughlin, M. J., Shepperd, W. (2001): Improving fertilizer efficiency on calcareous and alkaline soils with fluid sources of P, N, and Zn. - Plant and Soil 236: 209-219.

[15] Lombi, E., McLaughlin, M. J., Johnston, C., Armstrong, R. D., Holloway, R. E. (2004a). Mobility and lability of phosphorus from granular and fluid mono-ammonium phosphate differs in calcareous soil. - Soil Science Society of America Journal 68: 682-689.

[16] Lombi, E., McLaughlin, M. J., Johnston, C., Armstrong, R. D., Holloway, R. E. (2004b). Mobility, solubility, and lability of fluid and granular forms of $\mathrm{P}$ fertilizer in calcareous and non-calcareous soils under laboratory conditions. - Plant and Soil 269: 25-34.

[17] Marschner, P. (2012): Mineral Nutrition of Higher Plants. - Academic Press Elsevier, New York.

[18] McDowell, R. W., Sharply, A. N. (2001): Soil phosphorus fractions in solution: influence of fertilizer and manure, filtration and method of determination. - Chemosphere 45: 737748.

[19] Montalvo, D., Degryse, F., McLaughlin, M. J. (2014): Fluid fertilizers improve phosphorus diffusion but not lability in andisols and oxisols. - Soil Science Society of America Journal 78(1): 214-224.

[20] Mouazen, A. M., Kuang, B. (2016): On-line visible and near-infrared spectroscopy for infield phosphorous management. - Soil \& Tillage Research 155: 471-477.

[21] Quilty, J., Cattle, S. (2011): Use and understanding of organic amendments in Australian agriculture: a review. - Soil Research 49: 1-26. 
[22] Saavedra, C., Delgado, A. (2005): Phosphorus fractions and release patterns in typical Mediterranean soils. - Soil Science Society of America Journal 69: 607-615.

[23] Shand, C. A., Smith, S., Edwards, A. C., Fraser, A. R. (2000): Distribution of phosphorus in particulate, colloidal and molecular-sized fractions of soil solution. - Water Research 34: $1278-1284$.

[24] Snowball, K., Robson, A. D. (1983): Symptoms of Nutrient Deficiencies: Subterranean Clover and Wheat. - University of Western Australia, Perth.

[25] Stewart, W. M., Dibb, D. W., Johnston, A. E., Smyth, T. J. (2005): The contribution of commercial fertilizer nutrients to food production. - Agronomy Journal 97: 1-6.

[26] Syers, J. K., Johnston, A. E., Curtin, D. (2008): Efficiency of soil and fertilizer phosphorus use: reconciling changing concepts of soil phosphorus behavior with agronomic information. - FAO Fertilizer and Plant Nutrition Bulletin; 2008/18. Food and Agriculture Organization of the United Nations (FAO), Rome.

[27] Ulrich, A., Schnug, E. (2013): The modern P sustainability movement: a profiling experiment. - Sustainability 5: 4523-4545.

[28] Van Kauwenbergh, S. (2010): World Phosphate Rock Reserves and Resources. - IFDC Technical Bulletin 75. International Fertilizer Development Centre, Muscle Shoals, Alabama.

[29] Vance, P. C., Uhde-Stone, C., Allan, D. (2003): Phosphorus acquisition and use: Critical adaptations by plants for securing a nonrenewable resource. - New Phytologist 157: 423447.

[30] Von Wandruszka, R. (2006): Phosphorus retention in calcareous soils and the effect of organic matter on its mobility. - Geochemical Transactions 7: 6.

[31] Wang, Y., Thorup-Kristensen, K., Jensen, L. S., Magid, J. (2016): Vigorous root growth is a better indicator of early nutrient uptake than root hair traits in spring wheat grown under low fertility. - Frontiers in Plant Sciences 7: 865. DOI: 10.3389/fpls.2016.00865.

[32] Zhang, B. G., Chen, Q. X., Yang, Q., Liu, K. D. (2012): Effects of NPK deficiencies on root architecture and growth of cucumber. - International Journal of Agriculture and Biology 14: 145-148.

[33] Zhen-Yu, D., Qing-Hua, W., Fang-Chun, L., Hai-Lin, M., Bing-Yao, M., Malhi, S. S. (2013): Movement of phosphorus in a calcareous soil as affected by humic acid. Pedosphere 23: 229-235. 